\title{
TAXONOMIC SUMMARY OF OMALOTHECA (ASTERACEAE: INULEAE)
}

\author{
Guy L. Nesom \\ Department of Botany, University of Texas, Austin, Texas 78713 U.S.A.
}

\section{ABSTRACT}

The species of the genus Omalotheca Cass. are primarily Old World in distribution, but three extend in distribution into northeastern North America. Although the the genus has been included within Gnaphalium, its combination of spiciform capitulescences, papillate achenial surfaces and nonmyxogenic achenial hairs exclude it from that genus. A description and taxonomic summary of Omalotheca are provided.

KEY WORDS: Omalotheca, Gnaphalium, Asteraceae, Inuleae.

A group of species, distributed primarily from Europe to south central Asia, is sometimes segregated from Gnaphalium as the genus Omalotheca Cass. (e.g., Holub 1976), but there has been no consensus regarding the rank at which it should be treated (e.g., Grierson 1975; Rechinger 1980). The first comparative morphological study to include a broad range of species centered around Gnaphalium has been that of Drury (1970), and most subsequent opinions regarding Omalotheca are based at least in part on his study. Hilliard \& Burtt (1981) discussed some of the characters of Omalotheca but did not express a definite opinion regarding its rank.

In Drury's tabular arrangement of results, Omalotheca is a subgroup of GROUP I ("gnaphalioid cudweeds"), which is correlatively ranked with GROUP II (primarily Achyrocline, but including subgroups) and GROUP III (primarily Anaphalis). His arrangement however, provided no hypotheses regarding relationships among the subgroups and his delimitation of "subgroups" appears to have been more accurate than of "groups." As further noted by Hilliard \& Burtt (1981), Drury's representation of African species was severely limited and did not include many taxa that Hilliard \& Burtt have recognized as segregate genera. The composition of Drury's GROUP I is heterogeneous and the differences that separate the subgroups appear to be at least as significant as those used by Hilliard \& Burtt to delimit the numerous genera of southern Africa Gnaphaliinae. Omalotheca is clearly set apart from all other entities in Drury's study.

The species of Omalotheca are distinguished from other Gnaphaliinae in a combination of features, many of which were recorded by Drury (1970): 
herbaceous, rhizomatous and fibrous rooted perennials; leaves narrowly to linearly lanceolate; capitulescence spiciform; heads relatively large; phyllaries with nonfenestrated stereomes; pistillate corollas minutely but evidently papillate punctate; pollen grains relatively large; achenes $1.0-1.5 \mathrm{~mm}$ long, the surfaces imbricate-papillate, also with nonmyxogenic hairs 6-12 times longer than wide; and pappus bristles basally eciliate, separate or basally connate and released as a unit. Further, the very large pollen grains and distinctive achenial surfaces in Omalotheca were found by Drury elsewhere only in some species of the Achyrocline group (those species referred to Pseudognaphalium Kirpinczn.) rather than in the gnaphalioid group, and it is likely that the affinities of Omalotheca lie with that group. The achenial vestiture of Omalotheca removes it from Gnaphalium sensu stricto, the species of which have achenes with nonpapillate surfaces and commonly with myxogenic hairs.

Omalotheca is superficially similar to Gamochaeta (also placed by Drury in GROUP I) in its spicate capitulescences and (in some species) its connate pappus bristles, but the species of Gamochaeta differ in their smaller heads, concave receptacles, filiform corollas, smaller pollen grains, much smaller achenes with nonpapillate surfaces and often with myxogenic achenial hairs and fewer pappus bristles (Nesom 1990a). Further, Gamochaeta is strictly a New World genus with its center of diversity primarily in middle elevations of South America.

Euchiton Cass. (Gnaphalium sect. Euchiton [Cass.] DC.), a group of species from the western to southwestern Pacific region, has also been considered within the boundaries of Gnaphalium sensu stricto, but it is very different in habit, capitulescence and details of achenial morphology from Omalotheca (Drury 1970).

Of all groups of Gnaphaliinae, Omalotheca shows the greatest overall similarity to the two species of Mexerion (Nesom 1990b). The Mexican species differ, however, in their nonpapillate achenes with myxogenic duplex trichomes, apically fimbriate pistillate corollas and strictly tubular disc flowers with sterile achenes.

Omalotheca comprises eight species, five endemic to Europe and adjacent Asia, with three primarily Eurasian but also reaching boreal eastern North America. All occur in alpine or high elevation habitats. Chromosome numbers are known for $O$. supina ( $n=14$ pairs) and for $O$. sylvatica and $O$. norvegica ( $n=28$ pairs) (Holub 1976). The genus has been split at the subgeneric and generic levels (Kirpicznikov \& Kuprianova 1950; Kirpicznikov 1960), but both Drury (1970) and Hilliard \& Burtt (1981) have noted that Omalotheca, as a natural group, comprises species of both groups. Holub (1976) separated the infrageneric taxa by the following contrasts:

1. "Inflorescence with 1-10 capitula. Female florets in 1(-2) rows. Achenes obovoid, compressed; pappus-hairs stout, free, falling 
separately" subg. Omalotheca

1. "Inflorescence with 10-150 capitula. Female florets in several rows. Achenes cylindrical; pappus-hairs slender, connate at base, falling as a unit" .................................subg. Gamochaetiopsis

Additionally, the species of subg. Gamochaetiopsis are single stemmed from a short, lateral rhizome, in contrast to the more caespitose growth in the species of subg. Omalotheca.

A summary of the taxonomy of Omalotheca is presented here, but it does not represent a critical study of species boundaries. All species are based on taxa originally named in Gnaphalium.

Omalotheca Cass., Dict. Sci. Nat. 56:218. 1828. Type species: Omalotheca supina (L.) DC.

Herbaceous, fibrous rooted perennials, caespitose from a system of numerous, short, slender, ascending, rhizomatous branches or single stemmed from a single, short, lateral, rhizome. Stems densely woolly, erect, unbranched except for very short lateral branches in the lower part of the capitulescence. Leaves entire with flat to very slightly revolute margins, mostly narrowly lanceolate to oblanceolate, bicolored, densely woolly-sericeous beneath, greenish glabrescent above, the basal persistent in a rosette. Capitulescence spiciform or if few flowered, a compact, terminal glomerule, the spike usually continuous but sometimes slightly interrupted in the lower part. Phyllaries hyaline stramineous with a green, baso-medial patch, large and distinctively patterned, the stereome not divided or fenestrated. Pistillate flowers numerous, fertile, the corollas filiform-tubular, definitely lobed at the apex, gradually dilated toward the base, minutely but evidently papillate punctate. Hermaphroditic flowers few, fertile, 3-4 mm long, narrowly tubular but dilated at the throat; anthers tailed; style branches with collecting hairs confined to a blunt, apical patch. Achenes 1.0-1.5 mm long, obovoid to cylindric, the surfaces papillate, also with strigillose, spreading-appressed, duplex, nonmyxogenic hairs, 6-12 times longer than wide. Pappus monomorphic, of numerous, scabrid, basally eciliate, caducous bristles, separate or basally connate in a smooth ring and released as a unit. Base chromosome number, $x=14$, with diploids and tetraploids reported.

\section{Omalotheca subg. Omalotheca}

Gnaphalium sect. Omalotheca (Cass.) Endl., Gen. Pl. 6:447. 1838.

1. Omalotheca hoppeana (K. Koch) Schultz-Bip. \& F.W. Schulz, Arch. Fl. J. Bot. 311. 1861.

Central Europe. 
2. Omalotheca leucopilina (Boiss.) J. Holub, Folia Geobot. Phytotax. 11:81. 1976.

Turkey.

3. Omalotheca pichleri (Murb.) J. Holub, Bot. J. Linn. Soc. 71:271. 1976.

Yugoslavia and Albania.

4. Omalotheca roeseri (Boiss. \& Heldr.) J. Holub, Bot. J. Linn. Soc. 71:271. 1976.

\section{Greece.}

5. Omalotheca stewartii (C.B. Clarke) J. Holub, Folia Geobot. Phytotax. 12:429. 1977.

Omalotheca afghanica (Rech. f. \& Koie) Holub, fide Rechinger, 1980.

Eastern Himalayas in Pakistan and Afghanistan, to Iran and the Caucasus.

6. Omalotheca supina (L.) DC., Prodr. 6:245. 1838.

Northern Europe and the mountains of central and southern Europe, northern Iran and the Caucasus, also in boreal eastern North America (Gleason \& Cronquist 1963; Boivin 1966).

Omalotheca subg. Gamochaetiopsis Schultz-Bip. \& F.W. Schulz, Arch. Fl. J. Bot. 311. 1861 .

Synchaeta Kirpiczn. in Kirpiczn. \& Kuprian., Acta Inst. Bot. V.F. Komarov, Acad. Sci. U.R.S.S., Ser. 1, 9:33. Gnaphalium sect. Synchaeta (Kirpiczn.) Kirpiczn., Flora U.S.S.R. 25:397. 1959.

7. Omalotheca norvegica (Gunn.) Schultz-Bip. \& F.W. Schulz, Arch. Fl. J. Bot. 311. 1861.

Europe, also in boreal eastern North America (Gleason \& Cronquist 1963; Boivin 1966).

8. Omalotheca sylvatica (L.) Schultz-Bip. \& F.W. Schulz, Arch. Fl. J. Bot. 311. 1861.

Widespread in Europe, to Siberia and central Asia, Iran, and the Caucasus, also in boreal eastern North America (Gleason \& Cronquist 1963; Boivin 1966). According to Grierson (1975), including the following two synonyms: 
Omalotheca alpigena (K. Koch) J. Holub, Folia Geobot. Phytotax. 11:81. 1976.

Caucasus region of Russia.

Omalotheca caucasica (Somm. \& Lev.) Czerepanov, Pl. Vasc. U.R.S.S. 88. 1981.

Caucasus region of Russia.

\section{ACKNOWLEDGMENTS}

I thank Drs. Billie Turner and Michael Dillon for their review and comments on the manuscript.

\section{LITERATURE CITED}

Boivin, B. 1966. Enumeration des plantes du Canada. Naturaliste Can. 93:253-274.

Drury, D.G. 1970. A fresh approach to the classification of the genus Gnaphalium with special reference to the species present in New Zealand (Inuleae-Compositae). New Zealand J. Bot. 8:222-248.

Gleason, H.A. \& A. Cronquist. 1963. Manual of Vascular Plants of Northeastern United States and Adjacent Canada. Van Nostrand Co., Inc., Princeton, New Jersey.

Grierson, A.J.C. 1975. Gnaphalium. Flora of Turkey 5:97-100.

Hilliard, O.M. \& B.L. Burtt. 1981. Some generic concepts in CompositaeGnaphaliinae. Bot. J. Linn. Soc. 82:181-232.

Holub, J. 1976. Omalotheca Cass. Pp. 126-127 in Flora Europaea, Volume 4. Cambridge Univ. Press, Cambridge, England.

Kirpicznikov, M.E. 1960. Revisio specierum generum Gnaphalium L. (emend.), Synchaeta Kirp. et Omalotheca Cass. in U.R.S.S. crescentium. Notulae Systematicae 20:296-313. 
\& L.A. Kuprianova. 1950. "Morphological and palynological contri"butions to the understanding of the genera of the subtribe Gnaphaliinae" [in Russian]. Acta Inst. Bot. V.F. Komarov Acad. Sci. U.R.S.S., Ser. 1, 9:7-37.

Nesom, G.L. 1990a. The taxonomic status of Gamochaeta (Asteraceae: Inuleae) and the species of the United States. Phytologia 68:186-198.

1990b. Mexerion (Astereae: Inuleae), a new genus from México. Phytologia 68:247-254.

Rechinger, K.H. 1980. Gnaphalium. Flora Iranica 145:46-51. 


\section{$2 \mathrm{BHL}$ Biodiversity Heritage Library}

Nesom, G L. 1990. "Taxonomic summary of Omalotheca (Asteraceae: Inuleae)." Phytologia 68, 241-246. https://doi.org/10.5962/bhl.part.5796.

View This Item Online: https://www.biodiversitylibrary.org/item/47092

DOI: https://doi.org/10.5962/bhl.part.5796

Permalink: $\underline{\text { https://www.biodiversitylibrary.org/partpdf/5796 }}$

\section{Holding Institution}

New York Botanical Garden, LuEsther T. Mertz Library

\section{Sponsored by}

The LuEsther T Mertz Library, the New York Botanical Garden

\section{Copyright \& Reuse}

Copyright Status: In copyright. Digitized with the permission of the rights holder.

Rights Holder: Phytologia

License: http://creativecommons.org/licenses/by-nc-sa/3.0/

Rights: https://biodiversitylibrary.org/permissions

This document was created from content at the Biodiversity Heritage Library, the world's largest open access digital library for biodiversity literature and archives. Visit BHL at https://www.biodiversitylibrary.org. 